\title{
THE EFFECTS OF 2-HYDROXY CHALCONE AND ITS DERIVATIVE ON THE LARVAE AND ADULTS OF TRIBOLIUM CONFUSUM
}

\author{
Sofyan H. S. AL-Sinjari a *, Asaad Mohammed Mustafa ${ }^{\text {b }}$, Basim S. Ahmed ${ }^{\text {a }}$, Dilsher A. Mohammed Al-Sindi a \\ ${ }^{\text {a }}$ Department of Biology, Faculty of Science, University of Zakho, Zakho, Kurdistan Region, Iraq - (sofyan.sedo, basim.ahmed, \\ dilsher.mohammed)@uoz.edu.krd, \\ ${ }^{\mathrm{b}}$ Department of Chemistry, Faculty of Science, University of Zakho, Zakho, Kurdistan Region, Iraq - asaad.mustafa@uoz.edu.krd
}

Received: Jun, 2019 / Accepted: Sept., 2019 / Published: Sept.,2019

https://doi.org/10.25271/sjuoz.2019.7.3.584

\begin{abstract}
:
2-Hydroxy Chalcone and its derivatives (compounds 1and 2) were used in a toxicity test on the larvae and adults of confused flour beetle Tribolium confusum (Du Val). Mortality tests were done by applying different concentrations $(0.01,0.02$ and $0.04 \mathrm{ppm})$ on 2-Hydroxy Chalcone and its derivatives which were exposed by topical application with $5 \mu \mathrm{L}$ of each compound and the data were recorded after $24 \mathrm{~h}$ of treatments. The mortality \% of [7-Hydroxy-9-(pyridine-4-yl)-6H-benzo[C]chromen-6-one] in (compound 2) were $26.6,50$ and $76.67 \%$ and $16.67,36.67$ and $63.3 \%$ and $13.3,23.3$ and $36.6 \%$ to $3 \mathrm{rd}$, 5th instar larvae and adults, respectively. While in [ 3-thinyl-1-(2-hydroxynaphthyl) -1-propene] (compound 1), the mortality \% were 23.3, 40 and 66.6\% and $13.3,30$ and $56.6 \%$ and 6.6, 16.6 and $26.6 \%$ to $3 \mathrm{rd}$, 5th instar larvae and adults, respectively. The results indicated that (comp.2) was the most toxic one and (comp.1) was the least toxic to confused flour beetle when applied singly. The calculated LC50 values to (compound 2) were $0.019,0.028$ and $0.074 \mathrm{ppm}$ to $3 \mathrm{rd}$, 5th instar larvae and adults, respectively. While to (compound 1), the LC50 values were $0.025,0.034$ and $0.106 \mathrm{ppm}$ to $3 \mathrm{rd}$, 5 th instar larvae and adults, respectively. The order of toxicity of the chemical compounds was $2>1$. These chemical compounds can be used to control confused flour beetle.
\end{abstract}

KEYWORDS: Tribolium Confusum, Toxicity, Chalcones and its Derivatives.

\section{INTRODUCTION}

Tribolium confusum (Du Val) is considered as a suitable insect species for bioassays since it exhibits moderate tolerance to most insecticides (Champ and Campbell-Brown 1970). In this investigation, 2 chemical compounds ( 1 and 2) were used to evaluate their action on the confused flour beetle, Tribolium confusum (Du Val).

Confused flour beetle Tribolum confusum is one of the worldwide insect pests of mills, food warehouses, retail stores, and urban homes (Park, 2002 and Esmaili, et.al. 2013). The pest can cause damage to stored-products by feeding and hence severely reducing the quality of crops due to product excrement and larval feces. This pest makes serious damage on flour and crush cereal particularly at larval and adults stages. Also, the pest causes damage to the seeds containing high humidity (usually above $12 \%$ ) converting flour color to gray and creates bad smell see table2. The continuous exposure of the grain and flour to this pest encourages mold growth (Weston, and Rattlingourd 2000 and Park, 2002).

Recently, chlorinated hydrocarbons were replaced in confused flour beetle control program by pesticides of other chemical groups, especially by certain organophosphorous (O-P) insecticides (Pedigo, 1989). The O-P compounds selected are safer to humans and environment where it can effectively replace the chlorinated hydrocarbon (Smith, 1970 and Zettler \& Arthur, 2000).

Chalcones are one of the most popular compounds in plants, such as vegetables, fruits, tea, and have various pharmacological activities; as anti-inflammatory, antifungal, antimalarial, cytotoxic, anti-tumor, and anti-oxidant (Zhuang, 2017). In addition, it is a basic moiety of many heterocyclic systems containing $\mathrm{O}, \mathrm{S}$ and $\mathrm{N}$. $\mathrm{N}$ with heterocyclic derivatives synthesized from chalcones which exhibited anti-inflammatory, antioxidant, anti-tubercular and anti-bacterial activities. Naphthylchalcone and 2-hydroxy chalcones derivatives were proved to have activity and toxicity against mycobacterium tuberculosis at low concentrations with low cytotoxicity against human cells (Macaev, et. Al. 2014). Simplicity of their synthesis at low cost is an advantage of chalcones as potential antituberculosis. An attempt has been made to synthesize chalcone (comp.1) by the reaction of 2-acetyl thiophene with 2- hydroxy naphthylaldehyde. In addition, one of the chalcones derivatives was prepared as follow [pyridine-2-yl-6H-benzo[c] chromen-6one] (comp. 2). The synthesized compounds have been characterized by physical properties, IR, 1HNMR data.

\section{MATERIALS AND METHODS}

\section{Insect rearing}

The confused flour beetle adults were obtained from a laboratory colony of Department of Biology, Faculty of Science/ Zakho University. The pest was reared in $1000 \mathrm{ml}$ glass container. The insects were fed on flour containing $5 \%$ powdered dry yeast (Park, and Frank, 1948; Park, 1962; and Zyromska-Rudzka, 1966). The glass containers were maintained in the dark incubator (LAB TECH. Korea) at $30 \pm 1$ ${ }^{\circ} \mathrm{C}, 70 \pm 5 \%$ RH conditions. The $3^{\text {rd }}$ and $5^{\text {th }}$ instars larvae of $T$. confusum were used in the present experiments, whereas the adults age were 1 week after emergence.

\section{Chemistry}

Melting points were determined in an open capillary tube and were uncorrected. IR spectra were recorded on a Bruker -Alpha with Platinum-ART spectrometer (Germany). 1H- NMR spectra were recorded on a Bruker BioSpin Gmbh 100.65-MHz instrument in DMSO as solvent and TMS as an internal standard.

\footnotetext{
* Corresponding author

This is an open access under a CC BY-NC-SA 4.0 license (https://creativecommons.org/licenses/by-nc-sa/4.0/)
} 
<smiles>[R]c1cccc2c1oc(=O)c1c(O)cc(-c3ccncc3)cc12</smiles>

Fig 1. General procedure for synthesis of [6H-benzo[c]chromen-6one.] compound 2. (Galdino, 2011).
In the current study, 2 chalcones were synthesized by ClaisenSchmidt condensation (a modied Aldol condensation reaction) with minor modifications. The classical method for synthesis of chalcones involves reaction of equimolar amounts of 2-acetyl thiophene with 2-hydroxy naphthaldehydes at room temperature in presence of sodium hydroxide or potassium hydroxide as base catalyst to give the compounds 1 .

General procedure for synthesis of [6Hbenzo[c]chromen-6-one.] comp. 2 (Mazimba, 2015).

2-Hydroxy-Pyridin-4-yl-chalcone (2 $\mathrm{mmol})$, potassium carbonate powder $(20 \mathrm{~mol} \%)$ and ethyl-acetoacetate $(2 \mathrm{~mol})$ were taken in ethanol and stirred at $60{ }^{\circ} \mathrm{C}$ for $30 \mathrm{~min}$. Then, the reaction mixture was cooled and poured into cold water. The precipitated solid was collected by filtration and recrystallized in ethanol to give [7-Hydroxy-9-(pyridin-2-yl)-6Hbenzo[c]chromen-6-one] (Comp. 2).

Table 1. Physical properties and IR-spectra of compounds 1 and 2.

\begin{tabular}{|c|c|c|c|c|c|c|c|c|c|c|c|}
\hline \multirow[b]{2}{*}{$\mathrm{n}$} & \multirow[b]{2}{*}{ Nomenclature } & \multirow{2}{*}{$\begin{array}{l}\text { Chemica } \\
1 \text { formula }\end{array}$} & \multirow[b]{2}{*}{ Color } & \multirow{2}{*}{$\begin{array}{l}\text { M. } \\
\text { P. }\end{array}$} & \multirow[b]{2}{*}{ Solubility } & \multicolumn{6}{|c|}{ IR- $\mathrm{cm}^{-1}$} \\
\hline & & & & & & $\begin{array}{c}\mathrm{C}= \\
\mathrm{O}\end{array}$ & $\mathrm{C}=\mathrm{C}$ & $-\mathrm{OH}$ & $\mathrm{C}-\mathrm{O}$ & $=\mathrm{C}-\mathrm{H}$ & Aromatic \\
\hline 1 & $\begin{array}{c}\text { 3-thinyl-1-(2- } \\
\text { hydroxynaphthyl) } \\
\text {-1-propene }\end{array}$ & $\mathrm{C}_{17} \mathrm{H}_{12} \mathrm{SO}_{2}$ & Brown & $96-98$ & Ethanol & 1630 & 1586 & 3180 & 1160 & 2882 & $1458-741$ \\
\hline 2 & $\begin{array}{c}\text { 7-Hydroxy-9- } \\
\text { (pyridine-4-yl)- } \\
\text { 6H-benzo[C] } \\
\text { chromen-6-one }\end{array}$ & $\mathrm{C}_{18} \mathrm{H}_{11} \mathrm{NO}_{3}$ & $\begin{array}{l}\text { White } \\
\text { solid }\end{array}$ & $\begin{array}{l}160- \\
162\end{array}$ & Ethanol & 1649 & ---- & 3362 & $\begin{array}{c}1236 \\
1151 \\
\text { C-O-C }\end{array}$ & ---- & $1451-985$ \\
\hline
\end{tabular}

Table 2. 1HNMR-spectra of compounds 1 and 2.

\begin{tabular}{|c|c|c|c|c|c|c|}
\hline $\mathrm{n}$ & $\mathrm{C} \alpha-\mathrm{H}$ & $\mathrm{C} \beta-\mathrm{H}$ & Aromatic-H & $-\mathrm{OH}$ & Pyridinyl-H & Cromen-one-H \\
\hline 1 & $1 \mathrm{H}, 7.87, \mathrm{~d}$ & $1 \mathrm{H}, 8.12, \mathrm{~d}$ & $9 \mathrm{H}, 7.20-7.61, \mathrm{~m}$ & $1 \mathrm{H}, 12.05, \mathrm{~s}$ & ---- & --- \\
\hline 2 & ---- & ---- & $4 \mathrm{H}, 7.60-7.81, \mathrm{~m}$ & $1 \mathrm{H}, 8.8, \mathrm{~s}$ & $4 \mathrm{H}, 8.40-8.73, \mathrm{~m}$ & $2 \mathrm{H}, 7.10-7.20, \mathrm{dd}$ \\
\hline
\end{tabular}

\section{Bioassay}

Three different concentrations $0.01,0.02$ and $0.04 \mathrm{ppm}$ were used for $3^{\text {rd }}, 5^{\text {th }}$ instars larvae and adults of confused flour beetle. Compounds 1 and 2 were diluted with ethanol; 10 larvae and 10 adults were exposed by topical application (the solution was injected over the insect's thorax by 50 capacity microliter syringe) (Galdino, 2011) with $5 \mu \mathrm{L}$ of different compounds concentrations and covered by a Petri dish to prevent the escaping of the insects. The treatments were replicated 3 times and each replicate consisted of $103^{\text {rd }}, 5^{\text {th }}$ instar larvae and 10 adults, the control group received $5 \mu \mathrm{L}$ of $50 \%$ ethanol. The bioassay containers were maintained in a glass door incubator at $30 \pm 1{ }^{\circ} \mathrm{C}$ and $70 \% \pm 5$ relative humidity throughout the experimental. The mortality \% for larvae and adults was recorded after $24 \mathrm{~h}$. The mortality was corrected according to Abbott's (1925).

\section{Determination of lethal concentration (LC50)}

Deadly dose values were determined for $50 \%$ of the tested insects and Upper and lower confidence limits using a system called MS-DOS according to Probit. Exe, probit. Statistical analysis of the results of toxicological tests were calculated according to Finney (1971). So as to get low doses of the pesticide to kill $50 \%$ of the experiment insects.

\section{Statistical analysis}

All statistical analyses were performed with the Graph Pad Prism program (Version 6.01) (GraphPad Software, Finland) by a Newmanns- Keuls of one-way analysis of variance (ANOVA) and the data were expressed as means \pm standard error of mean
(SEM). In all tables the letters ( $a, b$ and $c)$ are representing significant differences in the means at the 0.05 , respectively.

\section{RESULTS AND DISCUSSION}

\section{Larvicidal activity of compounds 1 and 2.}

Table (3) shows the results of exposing the $3^{\text {rd }}$ instar larvae of T. confusum to compounds concentrations of $0.01,0.02$ and $0.04 \mathrm{ppm}$. Larval mortality was significantly different $(\mathrm{P}<0.05)$ among the 3 doses and control which were $26.6 \pm 3.33,50.0 \pm$ 0.08 and $76.67 \pm 3.33 \%$ with compound 2 , and $23.3 \pm 3.33,40.0$ \pm 0.14 and $66.6 \pm 3.33 \%$ with compound 1 , respectively. These results indicated that a concentration dependent mortality for both compounds were obvious. Also, Table (3) shows that the $\mathrm{LC}_{50}$ of compound $2(0.019 \mathrm{ppm})$ was more toxic than that of compound $1(0.025 \mathrm{ppm})$ on the $3^{\text {rd }}$ instar larvae of confused flour beetle. The present study revealed that compound 2 possesses a high level of potency as larvicide against $T$. confusum. Such a phenomenon was noticed in the $70 \%$ mortality of $3^{\text {rd }}$ instar larvae of compound 2 treatment with 0.04 ppm, while the mortality $\%$ reached $63.3 \%$ with $5^{\text {th }}$ instar larvae indicating a higher instar resistant with increasing larvae age.

Martin, et. Al. (2000) showed that the $1^{\text {st }}$ instar larvae of the Helicoverpa Armigera were very sensitive to the chemical pesticide and then the sensitivity decreased significantly in subsequent successive larval stages, where sensitivity decreased with advancement of larval instar. 
Table 3. Mortality $\%$, concentration value of $\mathrm{LC}_{50}$ for different concentrations of compounds 1 and 2 on the $3^{\text {rd }}$ instar larvae of $T$. confusum.

\begin{tabular}{|c|c|c|c|c|c|}
\hline \multirow{2}{*}{$\begin{array}{c}\text { Concentrations } \\
\text { Ppm }\end{array}$} & \multirow[b]{2}{*}{ Control } & \multicolumn{2}{|c|}{ Compound 2} & \multicolumn{2}{|c|}{ Compound 1} \\
\hline & & $\begin{array}{c}\% \\
\text { Mortality }\end{array}$ & $\mathrm{LC}_{50}$ & $\begin{array}{c}\% \\
\text { Mortality }\end{array}$ & $\mathrm{LC}_{50}$ \\
\hline 0.01 & \multirow{3}{*}{$\begin{array}{c}3.33^{\mathrm{a}_{ \pm}} \\
2.1\end{array}$} & $\begin{array}{l}26.6^{\mathrm{b}} \\
\pm 3.33\end{array}$ & \multirow{3}{*}{0.019} & $\begin{array}{l}23.3^{\mathrm{b}} \\
\pm 3.33\end{array}$ & \multirow{3}{*}{0.025} \\
\hline 0.02 & & $\begin{array}{c}50.0^{\mathrm{b}} \\
\pm 0.08\end{array}$ & & $\begin{array}{l}40.0^{\mathrm{c}} \\
\pm 0.14\end{array}$ & \\
\hline 0.04 & & $\begin{array}{l}76.67^{\mathrm{b}} \\
\pm 3.33\end{array}$ & & $\begin{array}{l}66.6^{\mathrm{b}} \\
\pm 3.33\end{array}$ & \\
\hline
\end{tabular}

Table (4) shows the results of exposing $5^{\text {th }}$ instar larvae of $T$. confusum to $0.01,0.02$ and $0.04 \mathrm{ppm}$ of compounds 1 and 2 . Significant differences were noticed $(\mathrm{P}<0.05)$ among the 3 doses and control where the larval mortality was $16.67 \pm 3.33$, $36.67 \pm 3.33$ and $63.3 \pm 3.33 \%$ with compound 2 and 13.3 $\pm 3.33, \quad 30.0 \pm 1.32$ and $56.6 \pm 3.31 \%$ with compound 1 , respectively. These results indicated that a concentration dependent mortality for both compounds were obvious. Also, Table (4) shows that the $\mathrm{LC}_{50}$ of (compound 2) $(0.028 \mathrm{ppm})$ was more toxic than that of (compound 1) $(0.034 \mathrm{ppm})$ on the $5^{\text {th }}$ instar larvae of confused flour beetle.

Table 4. Mortality \%, concentration value of $\mathrm{LC}_{50}$ for different concentrations of compounds 1 and 2 on $5^{\text {th }}$ instar larvae of $T$. confusum.

\begin{tabular}{|c|c|c|c|c|c|}
\hline \multirow{2}{*}{$\begin{array}{c}\text { Concentrati } \\
\text { ons } \\
\text { ppm }\end{array}$} & \multirow[b]{2}{*}{$\begin{array}{c}\text { Contro } \\
1\end{array}$} & \multicolumn{2}{|c|}{ Compound 2} & \multicolumn{2}{|c|}{ Compound 1} \\
\hline & & $\%$ Mortality & $\mathrm{LC}_{50}$ & $\begin{array}{c}\% \\
\text { Mortality }\end{array}$ & $\mathrm{LC}_{50}$ \\
\hline 0.01 & \multirow{3}{*}{$0^{\mathrm{a}}$} & $\begin{array}{l}16.67^{b} \\
\pm 3.33\end{array}$ & \multirow{3}{*}{$\begin{array}{c}0.02 \\
8\end{array}$} & $\begin{array}{c}13.3^{\mathrm{b}} \\
\pm 3.33\end{array}$ & \multirow{3}{*}{$\begin{array}{c}0.03 \\
4\end{array}$} \\
\hline 0.02 & & $\begin{array}{l}36.67^{\mathrm{c}} \\
\pm 3.33\end{array}$ & & $\begin{array}{l}30.0^{\mathrm{b}} \\
\pm 1.32\end{array}$ & \\
\hline 0.04 & & $\begin{array}{l}63.3^{\mathrm{b}} \\
\pm 3.33\end{array}$ & & $\begin{array}{l}56.6^{\mathrm{b}} \\
\pm 3.31\end{array}$ & \\
\hline
\end{tabular}

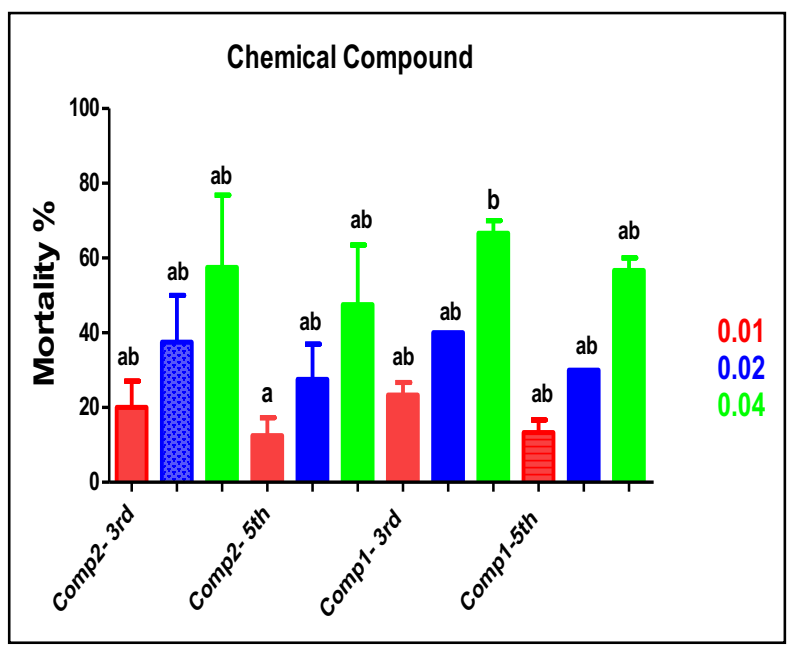

Figure 2. Effects of different concentrations of compounds 1 and 2 on the larval mortality of $T$. confusum

The present study showed that compounds 1 and 2 may induce insecticidal and larvicidal effects against $T$. confusum (Figure 1). The $\mathrm{LC}_{50}$ for both larval instars mortality was higher than the control group although the effect of compound 2 was more than the effect of compound 1. It is expected that smaller amounts of both compounds were sufficient to induce mortality in the larval stage.

\section{2- Adulticidal activity of the compounds 1 and 2}

The percentage of mortality on $T$. confusum adults with 0.01 , 0.02 and $0.04 \mathrm{ppm}$ of compounds 1 and 2 revealed significantly elevation $(\mathrm{P}<0.05)$ on all 3 doses when compared with the control group which were of $13.3 \pm 3.33,23.3 \pm 3.33$ and 36.6 $\pm 3.33 \%$ with compound 2 and $6.66 \pm 3.33,16.6 \pm 3.33$ and 26.6 $\pm 3.33 \%$ with compound 1 , respectively (see Table 5 ).

Table 5 also shows that the $\mathrm{LC}_{50}$ of (compound 2) (0.074 $\mathrm{ppm}$ ) was more toxic than that of (compound 1$)(0.106 \mathrm{ppm})$ on the of confused flour beetle.

Table 5. Mortality \%, concentrations value of $\mathrm{LC}_{50}$ for different concentrations of compounds 1 and 2 on T. confusum adults.

\begin{tabular}{|c|c|c|c|c|c|}
\hline \multirow{2}{*}{$\begin{array}{c}\text { Concentration } \\
\text { s } \\
\text { Ppm }\end{array}$} & \multirow[b]{2}{*}{$\begin{array}{c}\text { Contro } \\
1\end{array}$} & \multicolumn{2}{|c|}{ Compound 2} & \multicolumn{2}{|c|}{ Compound 1} \\
\hline & & $\begin{array}{c}\% \\
\text { Mortalit } \\
y\end{array}$ & $\mathrm{LC}_{50}$ & $\begin{array}{c}\% \\
\text { Mortalit } \\
y\end{array}$ & $\mathrm{LC}_{50}$ \\
\hline 0.01 & \multirow{3}{*}{$0^{\mathrm{a}}$} & $\begin{array}{r}13.3^{\mathrm{b}} \\
\pm 3.33\end{array}$ & \multirow{3}{*}{$\begin{array}{c}0.07 \\
4\end{array}$} & $\begin{array}{c}6.66^{\mathrm{c}} \\
\pm 3.33\end{array}$ & \multirow{3}{*}{$\begin{array}{c}0.10 \\
6\end{array}$} \\
\hline 0.02 & & $\begin{array}{r}23.3^{\mathrm{b}} \\
\pm 3.33\end{array}$ & & $\begin{array}{r}16.6^{\mathrm{b}} \\
\pm 3.33\end{array}$ & \\
\hline 0.04 & & $\begin{array}{r}36.6^{\mathrm{b}} \\
\pm 3.33\end{array}$ & & $\begin{array}{r}26.6^{c} \\
\pm 3.33\end{array}$ & \\
\hline
\end{tabular}

Cassida (1970) and Sun \& Johnson (1972) revealed that the basic mechanism of chemical action is to inhibit various oxidation enzymes. This confirms our conclusion about insect susceptibility to pesticides, which is mainly due to the different levels of metabolizing enzymes in the insecticide; this conclusion is consistent with the findings of Cassida, 1966 and Franklin, 1972 as the rate of inhibition depends on the chemical concentration.

The compounds containing hydroxy and methoxy substituents showed antioxidant activity. Chalcones showed a good insect antifeedant activity against the $4^{\text {th }}$ instar larvae Achoea Janata L. with castor leaf disc bio-assay method (Thirunarayanan, 2014).

\section{CONCLUSION}

In conclusion, the results of the present study revealed that $7-$ Hydroxy-9-(pyridine-4-yl)-6H-benzo[C] chromen-6-one (compound 2) showed significantly larvicidal and adulticidal against $T$. confusum than the 3-thinyl-1-(2-hydroxynaphthyl) 1-propene (compound 1) effects.

\section{REFERENCES}

Cassida, J. E. (1970). Mixed Function Oxidases Involvement In TheBiochemistry of Insecticide Synergists. J. Arg. Food. Chem. 18: 72-753.

Cassida, J. E.; Ngel, J. L.; Esaac, E. G.; Kamienski, F. X. and Kuwatsuka, S. (1966). Methylene C14-Dioxyphenyl compounds: Metabolism and Relation to Their Synergist Action. Science. 151: 1130-1135.

Champ, B.r. and Campbell-Brown M. (1970). Insecticide resistance in Amsterdam Tribolium castaneum Herbst (Coleoptera: Tenebrionidae) II Malathion resistance in Eastern Australia. J. Stored Prod. Res., 6: 111-131.

Esmaili, M; Samad V. and Ehsan P. (2013). Fumigant toxicity of essential oils of Mentha pulegium L. on adults of Callosobruchus maculatus, Tribolium castaneum, Lasioderma serricorne and Sitophilus oryzae in laboratory conditions. Technical Journal of Engineering and Applied Sciences 3(9):732-735.

Franklin, M. R. (1972). Pipronyl butoxide metabolism by cytochrome $\mathrm{p} 450$ : Factros affecting the formation and disappearance of the metabolite cytochrome p450 complex. J. Xenobiotica. 2: 517-527.

Galdino, T. V.; Picanço, M. C,; Morais, E. G. F.; Silva, N. R.; Rezende, G. A. and Lopes, M. C. (2011). Bioassay method for toxicity studies of insecticide formulations to tuta absoluta (MEYRICK, 1917). Departamento de Biologia Animal/DBA - Entomologia. Campus Universitário. Vol. 35, No. 5, p. 869877.

Macaev, F.; Boldescu, V.; Pogrebnoi, S. and Duca, G. (2014). Chalcone Scaffold based Antimycobacterial Agents. Med chem 4: 487-493.

Martin, T.; Ochou, G. O.; Hala, N.; Kio, F. and Vaissayer, M. (2000). Pyrethroids resistances in the cotton bollworm Helicoverl armigera (Hubner). West Africa Pest Manag. Sci. 56 (6): 549554. 
Mazimba, O. (2015). Antimicrobial activities of heterocycles derived from thienylchalcones, Journal of King Saud University Science (2015) 27, 42-48.

Mazimba, O., Majinda, R. R.. and Masesane, I. B. (2011). An efficient synthesis of flavans from salicylaldehyde and acetophenone derivatives.Tetrahedr. Lett. 52 (50), 6716-6718.

Park, T. (2002). Observations on the general Biology of the flour Beetle, Tribolium confusum. Quarterly Review of Biology, University of Chicago Press, 9, (1): 36- 54.

Park, T. and Frank, M. B. (1948). The fecundity and development of the flour beetle Tribolium castaneum and Tribolium confusum at three constant temperatures. Ecology, 29: 368-375.

Park, T., (1962). Beetles, competition and population. Sci., 138: 13691375.

Pedigo, P.L. (1989).Entomology pest management. Prentice Hall (Ind.) Pvt. Ltd., New Delhi, pp:646.

Smith, R. F., (1970). Pesticides: The use and limitations in pest management. In "Concepts of pest management" (R. L. Rabband, F. E. Guthrie, eds.). 103-113. North Carolina State University, Raleigh, North Carolina.

Sun, Y. P. and Johnson, E. R. (1972). Quasi-Synergism and Penetration of Insecticides. J. Econ. Entomol. 65: 349-353.

Thirunarayanan, G. (2014). Synthesis, antimicrobial, antioxidant and insect antifeedant activities of some aryl bicyclo[2.2.1]heptene-2-ylmethanones. QScience Connect. Bloomsbury Qatar Foundation Journals. http://dx.doi.org/ 10.5339/connect.2014.18.

Weston, P. A. and Rattlingourd P. L. (2000) Progeny production by Tribolium castaneum (Coleoptera: Tenebrionidae) and Oryzaephilus surinamensis (Coleoptera: Silvanidae) on maize previously infested by Sitotroga cerealla (Lepidoptera: Gelechiidae) Journal of Economic Entomology 93:533-536.

Zettler, J. L. and Arthur, F. H. (2000). Chemical control of stored product insects with fumigants and residual treatments. Crop Protection, 19: 577-582.

Zhuang, C.; Zhang, W.; Sheng, C.; Zhang, W.; Xing, C.;Miao, Z. Chalcone: A Privileged Structure in Medicinal Chemistry.Chem. Rev. 2017, 117, 7762-7810. (b) Singh, P.; Anand, A.; Kumar,V. Recent developments in biological activities of chalcones: A mini review. Eur. J. Med. Chem. 2014, 85, 758-777. (c) Sinha, S.; Medhi, B.;Sehgal, R. Chalcones as an Emerging Lead Molecule for AntimalarialTherapy: A Review. J. Mod. Med. Chem. 2013 1, 64-77.

Zyromska-Rudzka, H., (1966). Abundance and emigrations of Tribolium in a laboratory model. Ekol. Pol. A., 14: 491-518. 